\title{
Nitrogen and phosphorus removal from contaminated water by five aquatic plants
}

\author{
Xiaoyun $\mathrm{Fu}$ \\ College of Forestry Shenyang Agricultural University \\ Shenyang, China \\ fuxiaoyun1230@sina.com
}

\author{
Xingyuan He* \\ Institute of Applied Ecology, Chinese Academy of \\ Sciences (CAS) \\ Shenyang, China \\ xyhe@iae.ac.cn
}

\begin{abstract}
Five aquatic macrophytes, Acorus calamus, Lythrum salicaria, Monochoria korsakowii Alisma orientale and Sagittaria sagittifolia were tested for the relative growth rate (RGR) and abilities of removing total nitrogen(TN) and total phosphorus (TP) by the manipulative indoor experiment. Result revealed that the RGR of M. korsakowii was the highest(0.818) among the five macrophytes, while that of A.orientale was the lowest (0.172).Also the abilities of different macrophyte species to remove nitrogen and phosphorous contrast sharply with one another. The results showed that A. calamus, L. salicaria, M. korsakowii and A.orientale had stronger ability to remove $\mathrm{TN}$, the removal rates were $97.7 \%, 94.9 \%, 96.4 \%, 91.2 \%$ respectively. A. calamus and L. salicaria had stronger ability to remove $\mathrm{TP}$, the removal rates were $96.1 \%$ and $83.4 \%$. The order of $\mathrm{TN}$ purification capacities was: A. calamus $>$ M. korsakowii $>$ L. salicaria $>$ A. plantago-aquatic $>$ S. sagittifolia. But for TP, the order was A. calamus $>$ L. salicaria $>$ M. korsakowii $>$ A.orientale $>$ S. sagittifolia.
\end{abstract}

Keywords-aquatic macrophytes;total nitrogen; total phosphorus; removal; relative growth rate

\section{INTRODUCTION}

Nitrogen and phosphorus contained in agricultural effluents and industrial wastewaters are mainly responsible for eutrophication[1]. It is evident that eutrophication has become a serious water pollution in many countries. Hunhe River,one of the most important river in liaoning province, supply water to the seven cities[2]. Over the last two decades, with the population growth and the rapid economic development in the drainage area, nutrient-rich effluents have increasingly discharged into the river. This has resulted in severe contamination and eutrophication of this river[3]. Occurrence of eutrophication affect the lives of local people that depend upon these water sources for their daily requirements. Thus, efficient remediation methods for controlling eutrophication and restoring the aquatic ecosystem are being pursued.

In recent years, there has been an ever-increasing interest in the study of nutrient-accumulating plants for environmental remediation application, termed as 'phytoremediation'. One method of phytoremediation is phytoextraction, which uses aquatic plants to remove pollutants from contaminated waters by concentrating them in the harvestable aboveground parts[4].Previous studies have demonstrated the effective removal of inorganic nutrients $\mathrm{N}$ and $\mathrm{P}$ in wastewaters by using various aquatic macrophytes,such as Eichhornia crassipes[5,6], Cyperus papyrus[7], Typha latifolia[8],Pisitia stratiotes[9] and Phragmites communis[10] , in natural or semi-natural systems.Their growth is rapid and are effective to provide potential alternatives for treating agricultural effluents and industrial wastewaters. However, the geographical position will affect their purification capacity[11]. The experiment was taken on the basis of resource surveys to the wild aquatic plants in the upstream watershed of Hunhe and Acorus calamus, Lythrum salicaria, Monochoria korsakowii Alisma orientale and Sagittaria sagittifolia were choosen for experiment.

The present study is part of a larger investigation into management options for enhancing biological nutrient removal from wastewater using natural and constructed wetland technology. The objectives of this study were to compare the extent of nutrient (total nitrogen and total phosphorus) removal from wastewater by five local plant species Furthermore it can provide a reference for screening accumulators for phytoremediation of contaminated water in the northeast China.

\section{MATERIALS AND METHODS}

\section{A. Experimental set-up}

Five aquatic macrophytes, Acorus calamus, Lythrum salicaria,Monochoria korsakowii Alisma orientale and Sagittaria sagittifolia were collected from the field. Plants were carefully washed using tap water then distilled water to remove all the debris, then kept for 5 days in clean water to acclimatize. After the adaptation period, the plants were cultivated in $50 \%$ Yoshida solution for 1 week. Samples were transplanted to the clear culture buckets (diameter $8 \mathrm{~cm}$, height $15 \mathrm{~cm}$, volume 3.5 L), three plants for each. The nutrient medium was changed into $100 \%$ Yoshida solution for 1 week. Then the desired amounts of $\mathrm{NH}_{4} \mathrm{NO}_{3}, \mathrm{NaH}_{2} \mathrm{PO}_{4} \cdot 2 \mathrm{H}_{2} \mathrm{O}$ were dissolved in distilled water to achieve the appropriate contamination level: $\mathrm{TN} 14 \mathrm{mgL}^{-1}$, TP $3 \mathrm{mgL}^{-1}$.

Buckets and other non-biological materials were cleaned with $10 \% \mathrm{HCl}$ solution and thoroughly rinsed with distilled water before utilization. These plants were grown in experimental buckets filled with $3 \mathrm{~L}$ of artificial sewage in a greenhouse at a temperature of $23 \pm 2^{\circ} \mathrm{C}$. 
The experiment was conducted from July 1, 2011 to August 1, 2011. Fifteen clear culture buckets were used to establish five treatments with triple replication. The six treatments included five monocultures (A. calamus, L. salicaria, $M$. korsakowii, A.orientale and S. sagittifolia) and no plants (as control).

The microcosms were arranged in three rows and randomly placed. The contaminated water was continuously aerated with an aquarium air pump. Losses in culture volume due to evapotranspiration were countered by addition of deionized water to the original level every other day.

\section{B. Sampling and analysis}

During the course of the experiments, water samples of $250 \mathrm{ml}$ were collected every 7 days from each tank. Water samples were collected from water surface of the buckets and kept at $0-4{ }^{\circ} \mathrm{C}$ until analysis within $24 \mathrm{~h}$. The concentrations of total nitrogen (TN),total phosphorus (TP)were measured according to the Standard Methods for the Examination of Water and Wastewater as prescribed by American Public Health Association[12]. Removal of TN and TP was calculated using the following equation:

$$
\mathrm{R}(\%)=\left[\left(\mathrm{C}_{0}-\mathrm{C}_{\mathrm{t}}\right) / \mathrm{C}_{0}\right] \times 100
$$

where $\mathrm{C}_{0}$ and $\mathrm{C}_{\mathrm{t}}$ represent the initial concentration and final concentration, respectively.

After 30 days of incubation, dry weight was determined after drying the plants at $70^{\circ} \mathrm{C}$ until constant weight. The relative growth rate (RGR) was calculated as the ratio of dry weight difference between dry weight at the end of 30 days of incubation and dry weight at the beginning of the experiment over $\left[\left(\mathrm{Wt}_{30}-\mathrm{Wt}_{0}\right): \mathrm{Wt}_{0}\right]$.

The results were analyzed statistically by the SPSS (Version 11.0). One-way analysis of variance was carried out with SPSS11.0. The significant difference was set between treatments at $\mathrm{p}<0.05$ or $\mathrm{p}<0.01$. Multiple comparison was also made by the least significant difference (LSD) test.

\section{RESULTS AND DISCUSSION}

\section{A. The growth of five species}

The growth of five species was favorable at the end of experiment (Fig .1.). In principle, high nutrient removal efficiencies can be achieved due to the very high growth rates. $M$. korsakowii grew relatively rapidly, which was reflected by the RGR of 0.818 . The RGR of $S$. sagittifolia was the lowest (0.039) in the five marophytes.The LSD test has shown statistically significant difference $(\mathrm{p}<0.05)$ between $A$. calamus, L. salicaria, A.orientale, S. sagittifolia and M. korsakowii. The relative growth rate (RGR) of A. calamus, $L$. salicaria, A.orientale, and $S$. sagittifolia showed no significant difference. Physical and chemical processes associated with the water column and vegetation are primarily responsible for $\mathrm{N}$ and $\mathrm{P}$ removal from the overlying water[13]. Most macrophytes species can assimilate $\mathrm{N}$ and $\mathrm{P}$ directly through their roots, shoots and leaves[14]. It was inferred that M. korsakowii had a greater potential to extract nutrients from wastewater due to the thin and loose root mat that allows water-plant interaction.

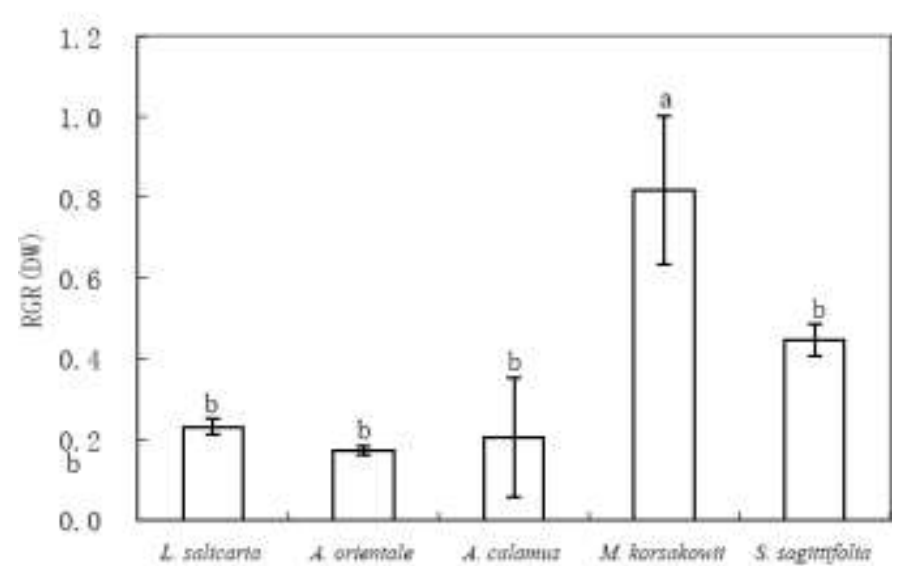

Figure 1. Relative growth rate (RGR) of five aquatic macrophytes in the experiment. Results are means \pm standard deviation $(n=3)$. Means with different letters are significant $(P<0.05)$ according to the LSD test.

\section{$B$. $N$ removal from the simulated wastewater}

The TN removal profiles from the simulated wastewater by the cultivars tested are shown in Fig .2. The five aquatic macrophytes could be effectively used in reducing the TN concentration compared to the control $(\mathrm{p}<0.01)$.

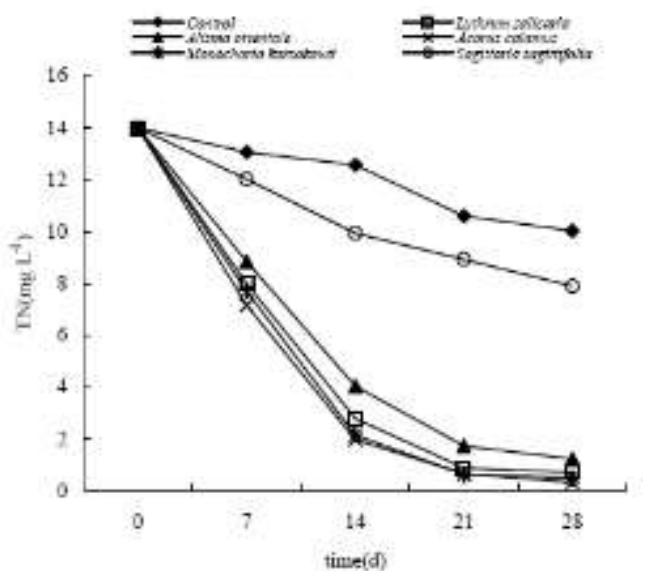

Figure 2. Total nitrogen $(\mathrm{TN})$ concentration $(\mathrm{mg} / \mathrm{L})$ of the wastewater

Except for $S$. sagittifolia, the TN concentration in other four species declined to a low level after be cultured for 21 days, and tended to level off in the latter 7 days. In particular, $A$. calamus had the best removal effect with the removal rates of $97.7 \%$ compared to $28.36 \%$ in control. L. salicaria, $M$. korsakowii and A.orientale had stronger ability to remove TN, the removal rates were $94.9 \%, 96.4 \%, 91.2 \%$ respectively(Table I ).The TN removal efficiency was found to be in the order of A. calamus $>M$. korsakowii $>L$. salicaria $>A$. orientale $>S$. sagittifolia. 
TABLE I . COMPARISON OF THE CONCENTRATION OF TN, TP BEFORE AND AFTER TRIAL (MEAN \pm SE)

\begin{tabular}{lllllll}
\hline \multirow{2}{*}{ Species } & \multicolumn{2}{c}{$\mathbf{C}_{\mathbf{0}}\left(\mathbf{m g ~ L}^{-1}\right)$} & \multicolumn{2}{l}{$\mathbf{C t}\left(\mathbf{m g ~ L}^{-\mathbf{1}}\right)$} & \multicolumn{3}{c}{$\mathbf{R}(\%)$} \\
\cline { 2 - 7 } & $\mathbf{T N}$ & $\mathbf{T P}$ & $\mathbf{T N}$ & $\mathbf{T P}$ & $\mathbf{T N}$ & $\mathbf{T P}$ \\
\hline L. salicaria & 14 & 3 & $0.711 \pm 0.051$ & $0.498 \pm 0.142$ & 94.9 & 83.4 \\
A. orientale & 14 & 3 & $1.238 \pm 0.195$ & $0.725 \pm 0.125$ & 91.2 & 75.8 \\
A. calamus & 14 & 3 & $0.323 \pm 0.095$ & $0.116 \pm 0.045$ & 97.7 & 96.1 \\
M. korsakowii & 14 & 3 & $0.507 \pm 0.076$ & $0.602 \pm 0.083$ & 96.4 & 79.9 \\
S. sagittifolia & 14 & 3 & $7.891 \pm 0.375$ & $1.806 \pm 0.098$ & 43.6 & 33.5 \\
Control & 14 & 3 & $10.030 \pm 1.175$ & $2.380 \pm 0.107$ & 28.4 & 20.7 \\
\hline
\end{tabular}

The inorganic forms are nitrate $\left(\mathrm{NO}_{3}\right)$, nitrite $\left(\mathrm{NO}_{2}\right)$, ammonia $\left(\mathrm{NH}_{3}\right)$, and ammonium $\left(\mathrm{NH}_{4}\right)$. Volatilization, plants or microbes uptake and oxidization of ammonia to nitrate in the nitrification process, are the main pathways of ammonia removal from the system. Nitrate and nitrite in this system are removed by plant uptake ordenitrification[15]. Once nitrogen has been denitrified, it is released in the atmosphere as nitrous oxide $\left(\mathrm{N}_{2} \mathrm{O}\right)$ or dinitrogen gas $\left(\mathrm{N}_{2}\right)$. Denitrification brings about the removal of nitrogen from the aqueous system and is the most important removal pathway for nitrogen in most wetlands [16].

\section{P removal from the simulated wastewater}

The TP removal profiles from the simulated wastewater by the cultivars tested are presented in Fig .3. The five aquatic macrophytes could be effectively used in reducing the TP concentration compared to the control $(\mathrm{p}<0.01)$.

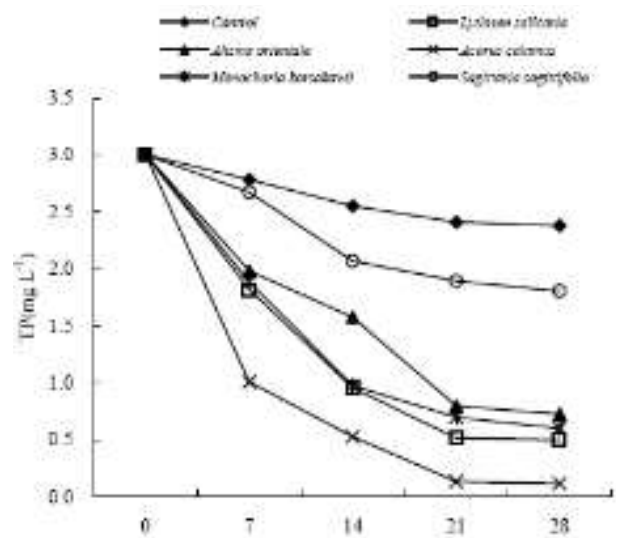

Figure 3. Total phosphorus (TP) concentration $(\mathrm{mg} / \mathrm{L})$ of the wastewater

The concentrations of TP had varying degrees decline in the treatment waters and the decline trends were essentially same. It declined rapidly in early 14 days, and became relatively stable after 21 days. The removal effect of $A$. calamus on TP was the best among all tested species; its removal rate was $96.1 \%$, followed by $L$. salicaria $(83.4 \%) . M$. korsakowii and A. orientale had stronger ability to remove TP, the removal rates were $79.9 \%$ and $75.8 \%$ (Table I ).

Three mechanisms associated with hydrophyte are involved in sequestering P. First, most aquatic macrophytes species can assimilate $\mathrm{P}$ directly through their thalli, shoots and leaves, a process that bypasses the soil nutrient reservoir.Second, periphyton growing on the hydrophyte can removes nutrients directly from the water. Third, the elevation in $\mathrm{pH}$ that results from intense aquatic macrophytes and periphyton photosynthesis can lead to $\mathrm{CaCO}_{3}$ supersaturation, which in turn may facilitate removal of $\mathrm{P}$ via coprecipitation[17,18]. We did not quantify the relative effect of each of the foregoing mechanisms on total nutrient removal in our study, although the partitioning of nutrient uptake has been investigated by others[19,20].

Although plant uptake played a significant role in the removal of $\mathrm{N}$ and $\mathrm{P}$, it did not account for all of the $\mathrm{N}$ and $\mathrm{P}$ loss from the system, indicating the possibility of biochemical and physico-chemical processes functioning in the system. The reductions of $\mathrm{N}$ and $\mathrm{P}$ observed in the control samples implied these processes were at work reducing nitrogen and phosphorus.

Studies done by using simulating conditions of "Micro-environment" have limitations. For example, the spatial scale does not generally reflect what occurs in nature, and abiotic conditions may be affected by the experimental conditions. Microcosms however, are extremely useful for controlled mechanistic investigations and have previously been used to test plants' ability to treat wastewater.

\section{CONCLUSIONS}

This study showed that five aquatic macrophytes could be used in reducing the $\mathrm{N}$ and $\mathrm{P}$ levels of nutrient enriched waters. Vegetated treatments had significantly lower TN and TP in the wastewater than unvegetated treatments. High growth rates and removal capacity of $M$. korsakowii suggested that the plant could be alternatively cultured in northeast China to maintain the treatment system efficiency at maximum level.

\section{ACKNOWLEDGEMENT}

This work was supported by the major technology projects: National water pollution control and management (No.2012ZX07202008). We also wish to thank Professor Guangzhu Zhou, for his help in preparing the manuscript.

\section{REFERENCES}

[1] V.H.Smith, G.D.Tilman and J.C.Nekola, "Eutrophication: impacts of excess nutrient inputs on freshwater, marine, and terrestrial ecosystem," Environment Pollution,vol.100, pp.179-19,1999.

[2] Y. Gao, W. Chen, W. Ding, "The influence of land use on water quality in the upper Hunhe River, northeast China;,"proceedings of the 2010 18th International Conference on Geoinformatics, Geoinformatics 2010, June 18, 2010 - June 20, 2010, Beijing, China, F, 2010 .

[3] W. Ding, X.He, W. Chen. "Runoff and Sediment Reduction by Riparian Buffer Filters on Steep Slopes;" proceedings of the International Conference on Computer Distributed Control and Intelligent Environmental Monitoring, 2011, Changsha, Hunan China, February 19-20, 2011

[4] W.J.Mitsch,, S.E.Jorgensen,. Ecological Engineering: An Introduction to Ecotechnology. John Wiley \& Sons, New York, pp.472, 1989.

[5] M.W.Jayaweera and J.C.Kasturiarachchi, "Removal of nitrogen and phosphorus from industrial wastewaters by phytoremediation using water hyacinth (Eichhornia crassipes)," Water Science Technology. vol..50, pp.217-225, 2010.

[6] D.J.Lin, S.H.J.Tang and J.W.He, "Purification of wastewater by Ipomoea aquatica and Eichhornia crassipes in a floating culture system," J. South Agric. China, Univ. vol. 25 , pp.14-17,2004.

[7] J.Kyambadde, F.Kansiime, L.Gumaelius and G Dalhammar, "A comparative study of Cyperus papyrus and Miscanthidium 
violaceum-based constructed wetlands for wastewater treatment in a tropical climate," Water Reserch,vol.38,pp.475-485,2009.

[8] L.H. Fraser, M.C. Spring and D. Steer, "A test of four plant species to reduce total nitrogen and total phosphorus from soil leachate in subsurface wetland microcosms," Bioresource Technology., vol.94, pp.185- 192,2004.

[9] R.D.Sooknah and A.C.Wilkie, "Nutrient removal by floating aquatic macrophytes cultured in anaerobically digested flushed dairy manure wastewater," Ecological Engineering, Vol.22, pp.27-42, 2004.

[10] N.Vaillant, M.Fabien and S.Huguette, "Use of commercial plant species in a hydroponic system to treat domestic wastewaters," Journal of Environmental Quality, vol. 33, pp.695-702,2004.

[11] APHA, Standard Methods for the Examination of Water and Wastewater, 20th ed. American Public Health Association, Washington, DC.1998.

[12] C.Forni, J.Chen, L.Tancioni1 and M.G.Caiola, "Evaluation of the fern Azolla for growth, nitrogen and phosphorus removal from wastewater," Water Reserch,vol.35, pp.1592-1598,2001.

[13] D.O.Huett, S.G.Morris, G.Smith and N.Hunt, "Nitrogen and phosphorus removal from plant nursery runoff in vegetated and unvegetated subsurface flow wetlands," Water Reserch,vol.39, pp..3259-3272,2005.
[14] W. Granéli and D. Solander, "Influence of aquatic macrophytes on phosphorus cycling in lakes,'Hydrobiologia, vol.170,pp..245-266,1988.

[15] E. Huertas, M. Folch, M. Salgot, I. Gonzalvo and C. Passarell, "Constructed wetlands effluent for streamflow augmentation in the Besòs River (Spain),” Desalination, vol.188, pp.141-147, 2006.

[16] Wang, Y.F. Gu, Z.Y. Zhu, B. Wu and D.Q. Yin, "Physiological responses of Ceratophyllum demersum under different nutritional conditions,". Journal of Applied Ecology, vol.16, pp.337-340,2005..

[17] Y.Q. Gan and Y.L. Guo, "Evaluation analysis and remedy strategy for eutrophication in Wuhan lake Donghu," Res. Environ. Yangtze Basin, vol.13, pp.277-281,2004.

[18] M.H.Hu, Y.S.Ao and X.E.Yang, "Comparative studies on the purification ability of economic plants in different $\mathrm{N}$ level eutrophic water," J. Soil Water Conserv. China,vol.21 , pp.147-150,2007.

[19] O.R.Zimmo, N.P.Van der Steen and H.J.Gijzen, "Nitrogen mass balance across pilot-scale algae and duckweed-based wastewater stabilisation ponds," Water Reserch ,vol..38 , pp.913-920,2004.

[20] P. Lombardo and G. Dennis Cooke, "Ceratophyllum demersum phosphorus interactions in nutrient enriched aquaria," Hydrobiologia, vol.497, pp.79-90, 2003. 